\title{
Upaya Meningkatkan Kemampuan Mengenal Koperasi Dalam Meningkatkan Kesejahteraan Keluarga Melalui Metode Picture And Picture Pada SD Negeri 023 Pandau Jaya
}

\author{
RISNAWATI \\ Sekolah Dasar Negeri 023 Pandau Jaya \\ Jln. AR. Rahim IV No. 1 Siak Hulu, Kampar \\ E-mail : risnawati@yahoo.com
}

\begin{abstract}
Social Lessons for elementary school students need a lot of methods in order to achieve effectiveness pembelejarannya. As in the social studies teachers need to implement a variety of methods. Case at 023 elementary schools Pandau Jaya require attention and of the study of literature allegedly using picture and picture can improve student understanding. Using action research method and samples of primary school and analyzed descriptively. The results showed that the portrait IPS learning already achieved the expected objective teacher performance indicators set out in> $85 \%$ of the number of students in a class have achieved mastery learning individually. There is a learning outcome IPS particularly in sub discussion of cooperatives in improving the welfare of the community, through teaching methods picture and picture already improving student understanding.
\end{abstract}

Keywords: Ability to know Cooperative, Methods Picture and Picture

Metode mengajar yang guru gunakan dalam setiap kali pertemuan di kelas bukanlah asal pakai, tetapi setelah melalui seleksi yang berkesesuaian dengan perumusan tujuan instruksional khusus. Jarang sekali guru merumuskan tujuan hanya dengan satu rumusan, tetapi pasti guru merumuskan lebih dari satu tujuan. Oleh sebab itu gurupun menggunakan metode yang lebih dari satu. Kegiatan belajar mengajar adalah sebuah interaksi yang bernilai pendidikan.Didalamnya terdapat interaksi edukatif antara guru dan peserta didik, ketika guru menyampaikan materi pelajaran kepada peserta didik di kelas. Materi pelajaran yang guru berikan itu akan kurang memberikan dorongan atau motivasi kepada peserta didik apabila penyampaiannya menggunakan strategi yang kurang akurat.Dalam hal inilah kehadiran metode menempati posisi penting dalam menyampaikan materi pelajaran.(Masjoko, 2010)

Materi pelajaran yang akan disampaikan tanpa memperhatikan pemakaian metode justru akan mempersulit guru dalam mencapai tujuan pembelajaran.pengalaman membuktikan bahwa kegagalan pengajaran salah satunya disebabkan oleh pemilihan metode yang kurang tepat. Hal ini sama seperti yang dijelaskan Syaiful (2010) bahwa kelas yang kurang bergairah dengan kondisi peserta didik yang kurang kreatif dikarenakan penentuan metode yang kurang sesuai dengan sifat bahan dan tidak sesuai dengan tujuan pengajaran.

Dengan demikian dapat dipahami bahwa metode adalah suatu cara yang memiliki nilai strategis dalam kegiatan belajar mengajar. Nilai strategisnya adalah metode dapat mempengaruhi jalannya belajar.Karena itu guru sebaiknya memperhatikan dalam pemilihan dan penentuan metode metode sebelum mengajar di kelas. (Masjoko, 2010)

Guru selalu memiliki metode dengan menerapkan strategi pembelajaran yang lebih menarik bagi siswa dan tidak membosankan agar dapat membangkitkan motivasi belajar siswa (Fauzi \& Dwiastuti, 2012) 
Model Picture and Picture juga memiliki suatu kelemahan. Kelemahan model Picture and Picture yaitu memakan banyak waktu serta siswa banyak yang pasif. Untuk mengatasi kelemahankelemahan model Picture and Picture maka ada beberapa hal yang harus diperhatikan yakni: (1) guru harus mempersiapkan sesuatu yang akan digunakan dalam pelaksanaan model Picture and Picture, (2) menjelaskan tujuan Picture and Picture kepada siswa, (3) memperhatikan situasi dan kondisi yang dapat mempengaruhi jalannya model Picture and Picture. Berdasarkan uraian di atas dapat disimpulkan bahwa model pembelajaran Picture and Picture adalah model pembelajaran yang dapat. mengembangkan keaktifan siswa dalam proses pembelajaran sehingga dapat menghindari kesalahan dalam memahami konsep-konsep, dapat meningkatkan motivasi belajar siswa serta dapat melatih kecakapan siswa dalam menganalisa sesuatu yang sedang berlangsung. (Nyoman et al., 2014)

Istarani dalam Nyoman (2013) kelebihan model pembelajaran picture and picture yaitu Materi yang diajarkan lebih terarah karena pada awal pembelajaran guru menjelaskan kompetensi yang harus dicapai dan materi secara singkat terlebih dahulu. Siswa lebih cepat menangkap materi ajar karena guru menunjukkan gambar-gambar mengenai materi yang diajarkan agar dapat meningkatkan daya nalar atau daya pikir siswa, karena siswa disuruh guru untuk menganalisa gambar yang ada. Dapat meningkatkan tanggung jawab siswa, sebab guru menanyakan alasan siswa mengurutkan gambar. Pembelajaran lebih berkesan, sebab siswa dapat mengamati langsung gambar yang telah dipersiapkan oleh guru. (Ni Nyoman Parwati, 2013)

Dalam penelitian tindakan kelas ini guru mengamati persoalan dan dilakukan tindakan sesuai dengan metode pembelajaran yang sesuai dengan persoalan yang ada. Adanya masalah dalam PTK dipicu oleh munculnya kesadaran pada diri guru bahwa praktik yang dilakukannya selama ini di kelas mempunyai masalah yang perlu diselesaikan. Dengan perkataan lain, guru merasa bahwa ada sesuatu yang perlu diperbaiki dalam praktik pembelajaran yang dilakukannya selama ini, dan perbaikan tersebut diprakarsai dari dalam diri guru sendiri (an inquiry of practice from within), bukan oleh orang dari luar. Tegasnya, kepedulian guru terhadap kualitas pembelajaran yang dikelolanya merupakan awal dari munculnya masalah yang perlu dicari jawabannya. Hal ini berbeda dengan penelitian biasa, yang secara umum adanya masalah ditengarai (ditandai) oleh peneliti yang biasanya berasal dari luar lingkungan yang mempunyai masalah tersebut. (Wardani, 2010)

Berfokus pada tingkat sekolah dasar sebagaimana dijelaskan bahwa pengenalan memang perlu diberikan kepada murid SD dengan memberikan pengenalan sebagaimana mata pelajaran IPS dengan sub materi pengenalan koperasi dalam meningkatkan kesejahteraan masyarakat, bagi murid SD N 023 kelas IV dinilai guru kelasnya masih belum optimal, dimana pengenalan terhadap koperasi ini masih sangat rendah.

Berdasarkan uraian masalah tersebut, maka melalui penerapan metode picture and picture diduga dapat mengatasi masalah yang dihadapi dalam belajar.

\section{METODE}

Prosedur penelitian tindakan kelas ini merujuk pada model Kurt Lewin yang terdiri atas empat komponen pokok penelitian kelas yakni: 1) perencanaan (planning), 2) tindakan (acting), 3) pengamatan (observing), dan 4) refleksi (reflecting). Menurut Zainal Aqib (2007:21), Model Kurt Lewin dapat digambarkan sebagai berikut:

1. Perencanaan. Pada tahap ini penulis menyusun rencana pembelajaran (RP) koperasi dalam meningkatkan kesejahteraan masyarakatPada 
74 Upaya Meningkatkan Kemampuan Mengenal Koperasi Dalam Meningkatkan Kesejahteraan Keluarga Melalui Metode Picture And Picture Pada SD Negeri 023 Pandau Jaya (Risnawati)

pelaksanaan siklus 1 direncanakan sebanyak 1 kali pertemuan.

2. Pelaksanaan. Penelitian tindakan kelas dilaksanakan selama pembelajaran berlangsung. Sebelumnya penulis melakukan beberapa hal antara lain: Guru menyampaikan tujuan pembelajaran yang akan dicapai; Guru menyajikan materi sebagai pengantar; Guru memperlihatkan gambar-gambar yang berkaitan dengan tujuan pembelajaran; Guru menunjuk/ memanggil murid secara bergantian memasang/ mengurutkan gambargambar yang telah di sediakan; Guru meminta agar murid menceritakan urutan gambar yang telah tersusun; Dari gambar tersebut guru mulai menanamkan konsep/materi sesuai dengan tujuan pembelajaran; dan penilaian

3. Observasi. Kegiatan observasi dilaksanakan secara kolaboratif dengan melibatkan rekan sejawat untuk mengamati tingkah laku dan sikap murid ketika mengikuti pembelajaran IPS yang menerapkan model picture and pictue dalam pembelajaran IPS.

4. Refleksi. setelah mengkaji hasil belajar IPS murid dan hasil pengamatan aktivitas guru, serta menyesuaikan dengan ketercapaian indikator kinerja maka peneliti mengubah strategi pada siklus dua agar pelaksanaannya lebih efektif.

Tindakan dilaksanakan pada siswa di SD Negeri 023 Pandau Jaya. Analisis data dalam penelitian tindakan kelas ini menggunakan analisis kuantitatif dan kualitatif (Supardi, 2006:131). Terhadap perolehan hasil belajar IPS dianalisis secara kuantitatif dengan memberikan nilai pada hasil belajar murid. Data-data tersebut dianalisis mulai dari siklus satu sampai dengan siklus tuga untuk dibandingkan dengan teknik deskriptif presentase

\section{HASIL}

Telah diketahui bahwa subjek penelitian berjumlah 32 murid. Pelaksanaan penelitian tindakan kelas ini dilakukan dalam 3 (tiga) siklus,. Berikut disajikan paparan hasil penelitian yang terdiri atas hasil belajar IPS melalui kolaborasi model pembelajaran picture and picture dan hasil observasi terhadap proses pembelajaran.

Berdasarkan data hasil penelitian siklus I mengenai hasil belajar IPS koperasi dalam meningkatkan kesejahteraan masyarakat, melalui model pembelajaran picture and picture diperoleh data untuk ketuntasan 70 sebanyak $64 \%$ atau 16 orang murid. Sedangkan yang tidak tuntas sebesar 9 atau 36\%, dan rata-rata hasil belajar sebesar 71. Selengkapnya dapat dibaca pada tabel distribusi frekuensi bergolong sesuai dengan kategori hasil belajar. Dari tabel diatas menunjukkan bahwa perolehan hasil belajar melalui metode picture and picture Siklus I ketuntasan individual baru mencapai 64\%. Potret pembelajaran IPS belum mencapai tujuan yang diharapkan guru yang tertuang dalam indikator kinerja $>85 \%$ dari jumlah murid dalam kelas telah mencapai ketuntasan belajar individual, sehingga perlu dilaksanakan siklus II.

Berdasarkan data hasil penelitian siklus I mengenai hasil belajar IPS koperasi dalam meningkatkan kesejahteraan masyarakat, melalui model pembelajaran picture and picture diperoleh data untuk ketuntasan 70 sebanyak 25 orang murid tuntas atau $72 \%$. Sedangkan yang tidak tuntas sebesar 1 atau $28 \%$ dan rata-rata hasil belajar sebesar 79. Selengkapnya dapat dibaca pada tabel distribusi frekuensi bergolong sesuai dengan kategori hasil belajar. Dari tabel diatas menunjukkan bahwa perolehan hasil belajar melalui metode picture and picture Siklus II ketuntasan individual baru mencapai $72 \%$. Potret pembelajaran IPS sudah mencapai tujuan yang diharapkan guru yang tertuang dalam indikator kinerja $>85 \%$ dari jumlah murid dalam kelas telah mencapai ketuntasan belajar individual, sehingga 
untuk kesempurnaan perlu dilaksanakan siklus III.

Berdasarkan data hasil penelitian siklus I mengenai hasil belajar IPS koperasi dalam meningkatkan kesejahteraan masyarakat, melalui model pembelajaran picture and picture diperoleh data untuk ketuntasan 70 sebanyak 25 orang murid tuntas atau $96 \%$. dan rata-rata hasil belajar sebesar 86 . Selengkapnya dapat dibaca pada tabel distribusi frekuensi bergolong sesuai dengan kategori hasil belajar sebagai berikut:

\section{Gambar 1: Nilai Tindakan Kelas}

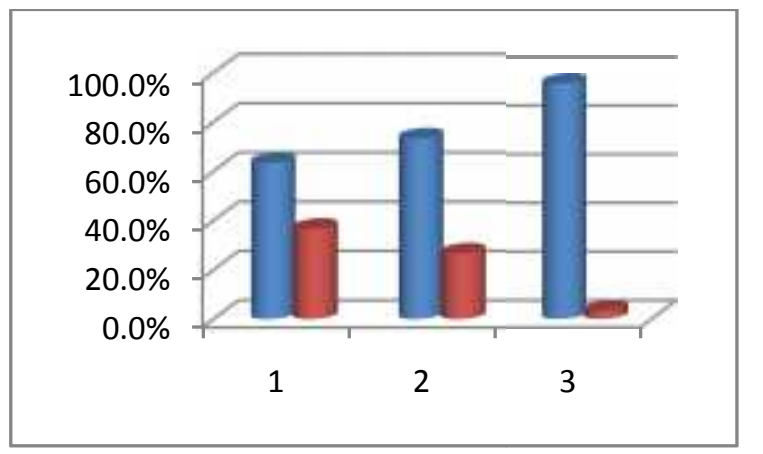

Hasil observassi pada siklus III diperoleh gambaran tentang sikap para murid dalam mengikuti pelajaran karena juga merupakan target pencapaian dalam pembelajaran sudah dirasakan baik, dari sudut guru kemampuan mengajar guru sudah baik, ada peningkatan yang signifikan. Guru sudah baik dalam mengelola ruang, fasilitas, strategi, interaksi dengan murid, dan evaluasi dengan baik juga untuk pengelolaan waktu sudah dapat terlaksana dengan efektif, karena guru sudah terbiasa menggunakan model pembelajaran. Kesan umum guru dalam mengajar sudah luwes dan sudah peka dengan kondisi murid.

Terbukti bahwa dalam penelitian ini membuktikan bahwa penerapan metode picture and picture dapat meningkatkan kemampuan mengenal koperasi dalam meningkatkan kesejahteraan masyarakat oleh murid. Dampak tersebut selain secara hard skill juga mampu meningkatkan kemampuan soft skill murid dalam belajar khususnya dalam hal sikap para murid dalam mengikuti pelajaran karena juga merupakan target pencapaian dalam pembelajaran sudah dirasakan baik, dimana sudah tumbuh semangat dan sudah memiliki toleransi di antara murid dan juga pantang menyerah di dalam menyelesaikan tugas yang diberikan guru di kelas jika dibandingkan dengan kondisi awal sebelum penerapan model picture and picture.

\section{PEMBAHASAN}

Potret pembelajaran IPS sudah mencapai tujuan yang diharapkan guru yang tertuang dalam indikator kinerja > $85 \%$ dari jumlah murid dalam kelas telah mencapai ketuntasan belajar individual. Terdapat peningkatan hasil belajar IPS materi khususnya pada sub bahasan koperasi dalam meningkatkan kesejahteraan masyarakat, melalui metode pembelajaran picture and picture sudah meningkatkan pemahaman murid.

Hasil penelitian ini sejalan dengan apa yang dikatakan Nyoman bahwa terjadi peningkatan perkembangan bahasa anak dengan media cerita gambar berseri pada siklus I sebesar $66,20 \%$ yang berada pada kategori sedang dan pada siklus II meningkat menjadi sebesar $83,30 \%$ yang berada pada kategori tinggi. Jadi dapat disimpulkan bahwa terjadi peningkatan perkembangan bahasa dengan menggunakan media cerita gambar berseri sebesar 17,10\%.(Nyoman et al., 2014)

Kemudian menurut Malini dalam hasil penelitiannya menunjukkan bahwa Hasil penelitian menunjukkan peningkatan keterampilan berbicara dengan penerapan model pembelajaran picture and picture dengan menggunakan media gambar pada siklus I sebesar 61,6 yang berada pada katagori sangat rendah dan mengalami peningkatan pada siklus II menjadi 95,2 yang tergolong pada katagori sangat aktif atau tinggi. (Malini, 2012)

Selain itu juga, bahwa: pembelajaran dengan menggunakan metode picture and picture pada pokok menulis cerita dapat meningkatkan keaktifan siswa kelas V SD Muhammadiyah 11 Mangkuyudan Surakarta. Keaktifan terlihat dari hasil observasi terhadap proses 
76 Upaya Meningkatkan Kemampuan Mengenal Koperasi Dalam Meningkatkan Kesejahteraan Keluarga Melalui Metode Picture And Picture Pada SD Negeri 023 Pandau Jaya (Risnawati)

pembelajaran siswa yaitu, sebelum tindakan sebesar $27 \%$, siklus II sebesar $60 \%$ dan siklus II sebesar $80 \%$; (2) pembelajaran dengan menggunakan metode picture and picture dapat meningkatkan kemampuan menulis cerita siswa kelas V SD Muhammadiyah 11 Mangkuyudan Surakarta. Peningkatan kemampuan menulis cerita terlihat dari hasil pekerjaan siswa yaitu, sebelum tindakan sebesar $30 \%$, siklus I sebesar $60 \%$, dan pada siklus II sebanyak 83\%. (Siti Mundziroh, 2013)

Kemudian bahwa penerapan model pembelajaran dengan menggunakan model pembelajaran kooperatif tipe Picture and Picture selain dapat meningkatkan hasil belajar mata pelajaran Matematika juga dapat meningkatkan aktivitas pembelajaran mata pelajaran Matematika pada siswa kelas IV Sekolah Dasar Kandang Roda Cibinong Bogor (Damayanti et al., 2013)

Berdasarkan hasil penelitian terdahulu terbukti bahwa penerapan metode picture and picture dapat meningkatkan kemampuan siswa dalam belajar.

\section{SIMPULAN}

Berdasarkan hasil penelitian yang dibahas dalam artikel ini maka dapat disimpulkan bahwa dengan penerapan metode picture and picture dapat meningkatkan kemampuan murid belajar mengenai koperasi dalam rangka meningkatkan kesejahteraan keluarga. Sehingga metode ini juga dapat dijadikan alat untuk pengembangan program materi pelajaran IPS ke depannya.

\section{DAFTAR RUJUKAN}

Damayanti, r., tampubolon, s., kurnia, d., kelas, p. T., dasar, i. V. S., penelitian, p., ... pakuan, u. (2013). And picture untuk meningkatkan hasil belajar mata, 1-7.

Fauzi, r., \& dwiastuti, s. (2012). Penerapan metode pembelajaran picture and picture untuk meningkatkan motivasi belajar biologi siswa kelas viii $\mathrm{d}$ smp negeri 14 surakarta tahun pelajaran 2011 / 2012, 3(september 2011), 7278.

Malini, n. K. S. (2012). Penerapan model pembelajaran picture and picture melalui media gambar untuk meningkatkan keterampilan berbicara pada anak taman kanak-kanak. Jurnal upg singaraja.

Masjoko. (2010). Metode belajar mengajar.

Ni nyoman parwati. (2013). Penerapan pembelajaran picture and picture berbantuan media kartu angka bergambar dapat.

Nyoman, n., trisnawati, 1., suarni, n. K., agung, a. A. G., pendidikan, j., pendidikan, g., ... ganesha, u. P. (2014). Penerapan metode picture and picture dengan media cerita gambar berseri untuk meningkatkan, 2(1).

Siti mundziroh. (2013). Peningkatan kemampuan menulis cerita dengan menggunakan metode picture and picture pada siswa sekolah dasar, 2(april), 1-10.

Wardani, k. (2010). Hakikat Penelitian Tindakan Kelas, 1-36.

Syaiful Bahari Djamarah dan Aswan Zain, Strategi Belajar Mengajar, (Jakarta: PT Rieneka CIpta, 2010), h. 76 